\title{
Assessment of serum trace element levels in rheumatic heart disease: A case-control study
}

\section{Romatizmal kalp hastalığında serum eser element seviyelerinin değerlendirilmesi: Bir vaka kontrol araştırması}

\author{
Mehmet Hakan Öncel ${ }^{1}$, Cemal Tuncer ${ }^{2}$
}

\section{Abstract}

Aim: Some trace elements play important roles in various heart diseases. In this study, we aimed to determine the changes in some trace element concentrations in the serum of patients with rheumatic heart disease (RHD). Methods: Sixty-one patients with RHD and 60 healthy subjects were included in the study. Six subgroups were defined in the study group according to the Wilkins score, the degree of aortic involvement, and the presence or absence of pulmonary hypertension. Selenium $(\mathrm{Se})$, Zinc $(\mathrm{Zn})$, and Cupper $(\mathrm{Cu})$ levels were measured, and transthoracic echocardiography was performed in all participants.

Results: Serum Se and $\mathrm{Zn}$ concentrations were significantly lower in the patients compared to the controls (mean \pm SD and p $43.08 \pm 1.83 \mu \mathrm{g} / \mathrm{dL}$ vs. $60.75 \pm 2.44 \mu \mathrm{g} / \mathrm{dL} ; \mathrm{t}=-5.305, \mathrm{p}=0.001$ and $64.65 \pm 2.77 \mu \mathrm{g} / \mathrm{dL}$ vs. $87.34 \pm 3.33 \mu \mathrm{g} / \mathrm{dL} ; \mathrm{t}=-5.458, \mathrm{p}=0.001$, respectively). However, the serum $\mathrm{Cu}$ concentration was significantly higher in the patient group than in the control group $(84.50 \pm 3.50 \mu \mathrm{g} / \mathrm{dL}$ vs. $74.23 \pm 3.08 \mu \mathrm{g} / \mathrm{dL} ; \mathrm{t}=2.309$, $\mathrm{p}=0.023$ ). Similarly, the $\mathrm{Cu} / \mathrm{Zn}$ ratio in the patient group was found to be significantly higher than the control group $(1.4 \pm 0.09 \mu \mathrm{g} / \mathrm{dL}$ vs. $0.9 \pm 0.04 \mu \mathrm{g} / \mathrm{dL} ; \mathrm{t}=5.267, \mathrm{p}=0.001)$. In the patient group, there was no significant relationship between the Wilkins score, aortic involvement, pulmonary hypertension, the serum trace element concentrations, and $\mathrm{Cu} / \mathrm{Zn}$ ratio ( $\mathrm{p}>0.05$ for all).

Conclusions: We conclude that the changes in the concentrations of the measured trace elements can predispose to RHD and play a role in the formation of certain factors that leads to the development of the disease. Besides, serum $\mathrm{Cu}$ levels and $\mathrm{Cu} / \mathrm{Zn}$ ratio can be used as inflammatory process markers.

Keywords: rheumatic heart disease; trace elements; selenium; zinc; copper

Öz

Amaç: Değişik kalp hastalıklarında bazı eser elementlerin önemli olduğu bilinmektedir. Bu çalışmada Romatizmal Kalp Hastalığı (RKH) olan hastaların serumunda bazı eser element konsantrasyonlarındaki değişiklikleri belirlemek ve bunun kronik RKH ve kapak tutulumunun şiddetiyle olan ilişkisinin ortaya konmas amaçlanmıștır.

Metod: RKH olan 61 hasta ve 60 sağlıklı birey çalıșma kapsamına alındı. Bu çalıșmaya alınan hasta grup, Wilkins skoruna, aort tutulumunun derecesine ve ayrıca pulmoner hipertansiyonun varlığı ve yokluğuna göre olmak üzere toplam altı alt gruba daha ayrıldı. Hastalara ayrıntılı fizik muayene ve laboratuvar incelemesinin yanında kan $\mathrm{Se}, \mathrm{Zn}$ ve $\mathrm{Cu}$ analizleri yapıldı. Hasta ve kontrol guruplarına transtorasik ekokardiografi ile ölçümler standart görünümleri üzerinden yapıldı.

Bulgular: Hasta grubunda serum Se ve Zn konsantrasyonu kontrol grubuna göre anlamlı ölçüde düşük bulundu (sirasiyla 43,08 $\pm 1,83 \mu \mathrm{g} / \mathrm{dL} ; 60,75 \pm 2,44 \mu \mathrm{g} / \mathrm{dL} ; \mathrm{p}<0,001$ ) ve $64,65 \pm 2,77 \mu \mathrm{g} / \mathrm{dL} ; 87,34 \pm 3,33 \mu \mathrm{g} / \mathrm{dL} ; \mathrm{p}<0.001$ ). Serum $\mathrm{Cu}$ konsantrasyonu hasta grubunda kontrol grubuna göre anlamlı ölçüde yüksek bulunmuștur $(84,5 \pm 3,5 \mu \mathrm{g} / \mathrm{dL}$ 'ye karşılık 74,23 $\pm 3,08 \mu \mathrm{g} / \mathrm{dL}, \mathrm{p}<0.05)$. Benzer şekilde $\mathrm{Cu} / \mathrm{Zn}$ oranı hasta grubunda kontrol grubuna göre anlamlı ölçüde yüksek bulunmuştur $(1,4 \pm 0,09 \mu \mathrm{g} / \mathrm{dL}$ ’ye karşılık $0,9 \pm 0,04 \mu \mathrm{g} / \mathrm{dL}, \mathrm{p}<0.001)$. Hasta grubunda serum eser element konsantrasyonları ve $\mathrm{Cu} / \mathrm{Zn}$ oranı ile hastalığın tutulum şiddetini gösteren Wilkins skoru, aort tutulumu ve pulmoner hipertansiyon arasında anlamlı bir ilişki bulunmamıştır ( $\mathrm{p}>0,05)$.

Sonuç: Eser element konsantrasyonundaki değișiklikler RKH'nı predispoze edebileceği gibi hastalığın gelişimine yol açan bazı faktörlerin ortaya çıkmasına da katkı sağlayabilir. Ek olarak artmış serum Cu seviyes ve $\mathrm{Cu} / \mathrm{Zn}$ oranı devam eden inflamatuvar proçes markırları olarak kullanılabilir.

Anahtar kelimeler: Romatizmal kalp hastalığı; eser element; selenyum; çinko; bakır
1 Şanlıurfa Mehmet Akif İnan Education Hospital, Department of Cardiology, Şanlıurfa, Turkey.

2 Kahramanmaraş Sütçü İmam University, Medical Faculty, Department of Cardiology, Kahramanmaraş, Turkey.

Ethics Committee Approval: The study wass approved by the local ethical authority.

Etik Kurul Onayı: Çalıșma lokal etik komite tarafindan onaylanmıştır.

Conflict of Interest: No conflict of interest was declared by the authors.

Çıkar Çatışması: Yazarlar çıkar çatışması bildirmemişlerdir.

Financial Disclosure: The authors declared that this study has received no financial support.

Finansal Destek: Yazarlar bu çalıșma için finansal destek almadıklarını beyan etmişlerdir.

Gelis Tarihi / Received: 06.08.2018

Kabul Tarihi / Accepted: 20.12.2018

Yayın Tarihi / Published: 15.03.2019

Sorumlu yazar / Corresponding author:

Mehmet Hakan Öncel

Sanlıurfa Mehmet Akif İnan Education Hospital,

Department of Cardiology

Şanliurfa, Turkey

e-posta: mhakanoncel@gmail.com

Tel/Phone: +905316703352

Copyright (C) ACEM 


\section{Introduction}

Acute rheumatic fever (ARF) is classified as a connective or collagen tissue disease. In this ailment, there is damage in the collagen fibrils and connective tissue. The disease presents with inflammatory reactions in many organs, including the heart, joints, and the central nervous system [1]. The most significant complication of ARF is fibrosis in the heart valves, which may lead to hemodynamic disturbance and chronic heart disease, causing acquired heart disease in children and young adults [2].

The effects of antioxidant trace elements on the response of cardiac tissue to oxidative stress is long known [3]. It has been suggested that abnormal immunoglobulin inflammatory responses may be related to changes in the trace element levels [4].

The role of oxidative stress in the etiology of cardiovascular disease has been regarded as promising concerning antioxidant therapies [5]. Despite the huge accumulation of knowledge, there are still conflicting reports on the significance of trace elements. Antioxidant supplementations were reported to be associated with no effect or even adverse disease outcomes [6].

We hypothesized that the serum Selenium (Se), Zinc $(\mathrm{Zn})$, and Cupper $(\mathrm{Cu})$ levels are lower in patients with rheumatic heart disease. Thus, the aim of this study was to determine some trace element concentrations in the serum of patients with RHD and to demonstrate the association of chronic RHD and the severity of valvular involvement.

\section{Material and methods}

\section{Study design}

A retrospective case-control study was conducted. Study reporting was done according to the STROBE criteria [7]. Ethical permit for conducting the study was obtained from the local ethics committee at the Kahramanmaraş Sütçü İmam University Medical Faculty (IRB number: 2006/4-3, date: 06/04/2006). The Helsinki Declaration was followed during all study processes.

\section{Setting}

The study was executed at the Kahramanmaraş Sütçü İmam University, Department of Cardiology between June 2005 and June 2006. During the study period, a total of 12,375 outpatients were served by the department.

\section{Participants}

Sixty-one patients (Group I) who applied to the cardiology polyclinics within one year meeting the revised Jones criteria [8] and 60 healthy controls (Group II) were included in the study. Healthy controls were selected from the visitors or caregivers of the study group. All control cases were interviewed and examined concerning the absence of the outcome. Six subgroups were defined among the patients, consisting of two according to Wilkins score [9] (Wilkins score 1-8 and $\geq 9$ ), two according to the degree of aortic involvement (no or mild involvement and moderate or severe involvement) [10], and two according to the state of pulmonary hypertension (present or absent).

Patients with known coronary artery disease, degenerative valve disease, congestive heart failure, cardiomyopathy, primary pulmonary hypertension, uncontrolled hyperthyroidism or hypothyroidism, chronic obstructive pulmonary disease, active ARF, active myocarditis, pericardial diseases, congenital heart diseases, renal or hepatic insufficiency, acute or chronic inflammation, infectious diseases, known malignancy, cerebrovascular disease, presence of major systemic disease, and age younger than 18 were excluded from the study. The study procedures were explained and written consent was obtained from all participants. The patients underwent a detailed physical examination and transthoracic echocardiography.

\section{Variables}

The main study outcomes were serum Selenium (Se), Zinc $(\mathrm{Zn})$, and Cupper $(\mathrm{Cu})$ levels. Samples for zinc $(\mathrm{Zn})$ and copper $(\mathrm{Cu})$ measurements were diluted with glycerol. Standards were prepared at concentrations of $50,100,200$, and $400 \mu \mathrm{g} / \mathrm{dL}$. Samples were measured and evaluated in a flame photometer against standard concentrations. Other variables studied were age, sex, systolic blood pressure $(\mathrm{mmHg})$, diastolic blood pressure $(\mathrm{mmHg})$, presence of hypertension or diabetes mellitus, smoking status, blood $\mathrm{Ca}(\mathrm{mg} / \mathrm{dL}), \mathrm{Mg}(\mathrm{mg} / \mathrm{dL}), \mathrm{P}(\mathrm{mg} / \mathrm{dL})$, alanine aminotransferase $(\mathrm{U} / \mathrm{L})$, aspartate transaminase $(\mathrm{U} / \mathrm{L})$, glucose $(\mathrm{mg} / \mathrm{dL})$, creatinine $(\mathrm{mg} / \mathrm{dL})$, total cholesterol $(\mathrm{mg} / \mathrm{dL})$, triglycerides $(\mathrm{mg} / \mathrm{dL})$, high-density lipoprotein $(\mathrm{mg} / \mathrm{dL})$, lowdensity lipoprotein $(\mathrm{mg} / \mathrm{dL})$, hemoglobin $(\mathrm{g} / \mathrm{dL})$, and hematocrit (\%) measurements.

Sample collection and storage was done while the participants were in the sitting position, drawing $10 \mathrm{ml}$ of venous blood from the forearm cubital vein using vacutainer tubes. After being kept in the room temperature for 30 minutes, the blood samples were centrifuged at $4000 \mathrm{rpm}$ for 15 minutes. Serum samples were transferred to another tube and stored in the deep freeze at $-20^{\circ} \mathrm{C}$ for analysis. For complete blood count (CBC), sufficient blood was obtained to an ethylenediaminetetraacetic acid (EDTA) tube. CBC, glucose, creatinine, aspartate transaminase (AST), alanine aminotransferase (ALT), total cholesterol, triglyceride, HDL (High-density lipoprotein), low-density lipoprotein (LDL), $\mathrm{Ca}, \mathrm{Mg}, \mathrm{P}$, and Fe levels were analyzed in the same day with the Behring RXL autoanalyser.

Samples for selenium (Se) measurement were diluted with $5 \%$ Triton $\mathrm{X} 100$. A mixture of palladium (Pd) and $\mathrm{Mg}$ (NO3)2 (magnesium nitrate) was used as matrix modifier. Standards were prepared at concentrations of 10, 20, 30, and 40 $\mu \mathrm{g} / \mathrm{L}$. Samples were run on an atomic absorption spectrophotometer using a graphite bath and the concentrations were evaluated according to the standard curve.

Transthoracic echocardiography was performed with the Acuson-Aspen ${ }^{\circledR}$ (Acuson Computer Sonography, Mountain View, California) device using a $3.5 \mathrm{MHz}$ probe. Echocardiographic examinations were performed using standard parasternal long axis, parasternal short axis, apical two spaces, apical four space, and apical five space views. Measurements of left ventricular (LV) end-diastole diameter, end-systolic diameter, posterior wall thickness, interventricular septum thickness, ejection fraction, fractional shortening, left atrium (LA) and aortic root were done by the M-mode echocardiography as defined by the American Echocardiography Society [11]. The systolic pulmonary artery pressure was calculated from the tricuspid insufficiency jet flow using the Bernoulli equation by adding the right atrial pressure. In addition, grading of the mitral valve characteristics by echocardiographic examination was performed using the Massachusetts General Hospital Score for Mitral valve morphology (Wilkins scoring) [9]. Two-dimensional, M-mode and double echocardiography methods were used in the assessment of aortic involvement [12-15]. Transesophageal echocardiography (TEE) was performed in patients where transthoracic echocardiography was inadequate due to a poor acoustic window [16].

\section{Study size}

Sample size calculation revealed that a total sample of 120 cases (60 study +60 controls) would be enough to detect a 
difference of $1.5 \mu \mathrm{g} / \mathrm{dl}$ difference in the serum $\mathrm{Zn}$ levels between the study and control groups using the Independent Samples ttest with a two-tailed hypothesis given a mean 1 of $60 \mu \mathrm{g} / \mathrm{dl}$ and mean $258.5 \mu \mathrm{g} / \mathrm{dl}$, standard deviation of 2 (effect size 0.6 ), alpha error of $5 \%$ with a power of $90 \%$ [17].

\section{Statistical methods}

Clinical, laboratory, and echocardiographic data were compared between Group I and Group II. Data were presented as mean \pm standard deviation (SD) or median (min-max). The numerical variables were checked for normal distribution. Variables with normal distribution were analyzed with the Independent Samples t-test whereas the Mann-Whitney U test was used for skewed data. The Chi-Square test was used for the comparisons between categorical variables. All statistical analyzes were done with the statistical package program SPSS (version 13.0). A p-value less than 0.05 was accepted as statistically significant.

\section{Results}

\section{Participants}

A total of 121 participants (Group I: $n=61$; Group II: $\mathrm{n}=60$ controls) were included in the study. Of the 61 patients in Group I, 15 (24.6\%) were males, and 46 (75.4\%) were females, while from the 60 controls in Group II 18 (30\%) were males and $42(70 \%)$ were females.

\section{Descriptive data}

The mean age of the participants was $37.02 \pm 1.25$ years in Group I and $38.95 \pm 1.44$ years in Group II. There was no significant difference between the groups concerning the demographic and clinical characteristics ( $>0.05$ for all) (Table $1)$.

Table 1: Comparison of demographic features and blood chemistry between Group I and Group II.

\begin{tabular}{|c|c|c|c|}
\hline Variable & Group I $(n=61)$ & Group II $(n=60)$ & $\mathrm{p}$ \\
\hline Age $\left(\right.$ years) ${ }^{*}$ & $38.95 \pm 1.44(18-64)$ & $37.02 \pm 1.25(18-61)$ & 0.313 \\
\hline Male/female & $15 / 46$ & $18 / 42$ & 0.508 \\
\hline $\begin{array}{l}\text { Systolic blood pressure } \\
(\mathrm{mmHg})^{¥}\end{array}$ & $119.18 \pm 1.83(100-160)$ & $120.08 \pm 1.80(90-160)$ & 0.855 \\
\hline $\begin{array}{l}\text { Diastolic blood } \\
\text { pressure }(\mathrm{mmHg})^{q}\end{array}$ & $73.28 \pm 1.32(50-100)$ & $75.68 \pm 1.21(60-100)$ & 0.116 \\
\hline Hypertension ${ }^{\beta}$ & $5 / 61(8.2)$ & $4 / 60(6.7)$ & 0.751 \\
\hline Diabetes mellitus $^{\beta}$ & $3 / 61(4.9)$ & $2 / 60(3.3)$ & 0.665 \\
\hline Smokers $^{\beta}$ & $6 / 61(9.8)$ & $7 / 60(11.7)$ & 0.551 \\
\hline $\mathrm{Ca}(\mathrm{mg} / \mathrm{dL})^{*}$ & $8.96 \pm 0.06(7.9-10)$ & $9.03 \pm 0.06(7.8-10)$ & 0.381 \\
\hline $\operatorname{Mg}(\mathrm{mg} / \mathrm{dL})^{*}$ & $1.83 \pm 0.03(1.20-2.30)$ & $1.87 \pm 0.07(1.40-5.70)$ & 0.729 \\
\hline $\mathrm{P}(\mathrm{mg} / \mathrm{dL})^{u^{\prime}}$ & $3.47 \pm 0.08(2.30-5.90)$ & $3.29 \pm 0.06(2.30-4.60)$ & 0.090 \\
\hline $\operatorname{ALT}(\mathrm{U} / \mathrm{L})^{*}$ & $38.38 \pm 2.10(15-105)$ & $40.05 \pm 1.80(16-93)$ & 0.096 \\
\hline $\operatorname{AST}(\mathrm{U} / \mathrm{L})^{*}$ & $25.92 \pm 1.55(14-72)$ & $24.26 \pm 1.31(12-66)$ & 0.249 \\
\hline Glucose $(\mathrm{mg} / \mathrm{dL})^{\mathrm{Y}}$ & $94.20 \pm 1.79(69-137)$ & $92.87 \pm 1.67(75-134)$ & 0.173 \\
\hline Creatinine $(\mathrm{mg} / \mathrm{dL})^{\Psi}$ & $0.79 \pm 0.03(0.10-1.40)$ & $0.74 \pm 0.02(0.10-1.40)$ & 0.093 \\
\hline Total cholesterol $(\mathrm{mg} / \mathrm{dL})^{q}$ & $162.35 \pm 4.54(95-240)$ & $172.06 \pm 3.96(117-228)$ & 0.193 \\
\hline Triglycerides $(\mathrm{mg} / \mathrm{dL})^{*}$ & $118.34 \pm 8.45(26-339)$ & $135.93 \pm 9.15(33-306)$ & 0.160 \\
\hline $\operatorname{HDL}(\mathrm{mg} / \mathrm{dL})^{*}$ & $43.62 \pm 1.45(22-71)$ & $42.00 \pm 1.53(26-96)$ & 0.444 \\
\hline $\operatorname{LDL}(\mathrm{mg} / \mathrm{dL})^{x}$ & $98.58 \pm 3.4(45.8-189.2)$ & $\begin{array}{c}108.33 \pm 3.84(44.8- \\
175.2)\end{array}$ & 0.206 \\
\hline Hem & $12.92 \pm 0.17(8.7-17.1)$ & $13.40 \pm 0.20(9.03-16.50)$ & 0.876 \\
\hline Hematocrit $(\%)^{*}$ & $\begin{array}{c}38.46 \pm 0.75(24.37- \\
47.30)\end{array}$ & $\begin{array}{c}39.75 \pm 0.56(27.70- \\
46.90)\end{array}$ & 0.468 \\
\hline
\end{tabular}

$¥:$ Mean \pm standard deviation (range), $\beta$ : $\mathrm{n}(\%)$, RHD: Rheumatic Heart Disease; AST: Aspartate transaminase; ALT: Alanine aminotransferase; HDL: High-density lipoprotein, LDL: Low-density lipoprotein

\section{Outcome data}

The two groups were compared regarding cardiac functions. There was no significant difference in the LV enddiastole diameters, aortic root diameters, posterior wall and septum thicknesses between Group I and Group II with echocardiographic measurements ( $p>0.05$ for all). However, significantly higher values for LV end-systolic diameter, lower ejection fraction levels, lower fractional shortening, and higher left atrium diameters were observed in the Group I compared to the Group II (Table 2).
Table 2: Comparison of transthoracic echocardiography measurements between the groups.

\begin{tabular}{|c|c|c|c|}
\hline Variable & Group I $(n=61)$ & Group II (n=60) & $\mathrm{p}$ \\
\hline $\begin{array}{l}\text { LV end-diastole diameter } \\
(\mathrm{cm})^{¥}\end{array}$ & $4.69 \pm 0.08(2.24-6)$ & $4.57 \pm 0.06(3.66-5.36)$ & 0.591 \\
\hline $\begin{array}{l}\text { LV end-systole diameter } \\
(\mathrm{cm})^{¥}\end{array}$ & $2.95 \pm 0.06(2.00-4.40)$ & $3.67 \pm 0.06(1.90-3.51)$ & 0.976 \\
\hline Ejection fraction ${ }^{*}$ & $65.75 \pm 1.08(45.0-79.0)$ & $69.83 \pm 0.93(58.0-83.0)$ & 0.542 \\
\hline Fractional shortening ${ }^{*}$ & $37.26 \pm 0.88(25.0-48.0)$ & $40.84 \pm 1.03(31.0-51.0)$ & 0.388 \\
\hline $\begin{array}{l}\text { Interventricular septum } \\
\text { thickness }(\mathrm{cm})^{¥}\end{array}$ & $1.03 \pm 0.02(0.70-1.50)$ & $0.98 \pm 0.02(0.66-1.30)$ & 0.758 \\
\hline $\begin{array}{l}\text { LV posterior wall } \\
\text { thickness }(\mathrm{cm})^{*}\end{array}$ & $0.91 \pm 0.02(0.64-1.40)$ & $0.87 \pm 0.02(0.58-1.10)$ & 0.930 \\
\hline $\begin{array}{l}\text { Left atrium diameter } \\
(\mathrm{cm})^{¥}\end{array}$ & $3.84 \pm 0.14(2.30-7.30)$ & $2.90 \pm 0.07(2.18-4.10)$ & 0.546 \\
\hline Aorta diameter $(\mathrm{cm})^{*}$ & $2.62 \pm 0.05(1.83-3.30)$ & $2.68 \pm 0.05(2.05-3.47)$ & 0.907 \\
\hline
\end{tabular}

$¥:$ Mean \pm standard deviation (range), LV: the left ventricle

Serum Se and $\mathrm{Zn}$ concentrations in the Group I were significantly lower than in Group II. Se values for the patient and control groups were $43.08 \pm 1.83$ and $60.75 \pm 2.44$, respectively $(\mathrm{t}=-5.305, \mathrm{p}<0.001)$, while the $\mathrm{Zn}$ values were $64.65 \pm 2.77$ and $87.34 \pm 3.33$, respectively $(\mathrm{t}=-5.458, \quad \mathrm{p}<0.001)$. Serum $\mathrm{Cu}$ concentrations were significantly higher in the Group I compared to the Group II $(84.5 \pm 3.5$ vs. $74.23 \pm 3.08$, respectively) $(\mathrm{t}=2.309$, $\mathrm{p}=0.023$ ) (Figure 1). Similarly, the $\mathrm{Cu} / \mathrm{Zn}$ ratio was significantly higher in the Group I than the Group II $(1.4 \pm 0.09$ vs. $0.9 \pm 0.04)$, $(\mathrm{Z}=4.588, \mathrm{p}=0.001)$ (Table 3$)$.

Figure 1: Comparison of the mean serum trace element values between the groups.

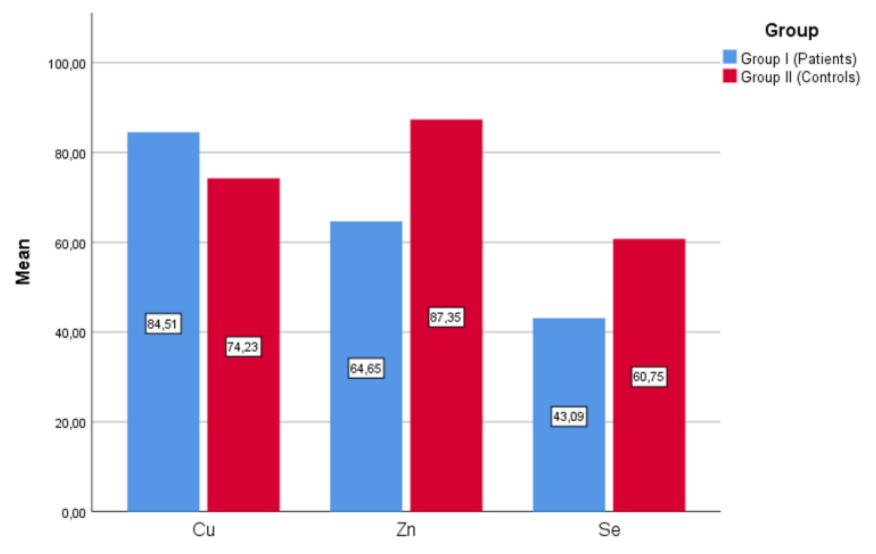

Table 3: Comparison of serum trace element levels between the groups.

\begin{tabular}{lccc} 
Variable & Group I $(\mathrm{n}=61)$ & Group II $(\mathrm{n}=60)$ & $\mathrm{p}$ \\
\hline $\mathrm{Se}(\mu \mathrm{g} / \mathrm{dL})^{*}$ & $43.08 \pm 1.83(9.77-79.65)$ & $60.75 \pm 2.44(10.77-107.88)$ & 0.001 \\
$\mathrm{Zn}(\mu \mathrm{g} / \mathrm{dL})^{*}$ & $64.65 \pm 2.77(30.15-109.4)$ & $87.34 \pm 3.33(57.16-166.84)$ & 0.001 \\
$\mathrm{Cu}(\mu \mathrm{g} / \mathrm{dL})^{*}$ & $84.50 \pm 3.5(37.32-167.92)$ & $74.23 \pm 3.08(38.20-133.10)$ & 0.023 \\
$\mathrm{Cu} / \mathrm{Zn}(\mathrm{ratio})^{*}$ & $1.40 \pm 0.09(0.58-2.84)$ & $0.90 \pm 0.04(0.04-1.82)$ & 0.001 \\
\hline
\end{tabular}
$\mathrm{Cu} / \mathrm{Zn}$ (ratio) $\quad 1.40 \pm 0.09(0.58-2.84) \quad 0.90 \pm 0.04(0.04-1.82)$

$¥:$ Mean \pm standard deviation (range)

Mean serum Se and $\mathrm{Zn}$ values were slightly higher $(45.74 \mu \mathrm{g} / \mathrm{dl}$ vs. $42.29 \mu \mathrm{g} / \mathrm{dl}$ and $73.49 \mu \mathrm{g} / \mathrm{dl}$ vs. $61.98 \mu \mathrm{g} / \mathrm{dl}$, respectively), while the serum $\mathrm{Cu}$ concentrations were slightly lower $(85.53 \mu \mathrm{g} / \mathrm{dl}$ vs. $81.59 \mu \mathrm{g} / \mathrm{dl})$ among the patients with a Wilkins score of $>8$. However, there was no significant relationship between the serum trace element concentrations and $\mathrm{Cu} / \mathrm{Zn}$ ratio depending on the Wilkins score groups in the patients $(\mathrm{p}>0.05)$ (Table 4).

Table 4: Comparison of serum trace element levels between Wilkins score groups.

\begin{tabular}{lccc} 
& Wilkins Score 1-8 $(\mathrm{n}=47)$ & Wilkins Score >8 $(\mathrm{n}=14)$ & $\mathrm{p}$ \\
\hline $\mathrm{Se}(\mu \mathrm{g} / \mathrm{dL})^{*}$ & $42.29 \pm 2.06(9.77-72.15)$ & $45.74 \pm 4.06(23.97-79.65)$ & 0.444 \\
$\mathrm{Zn}(\mu \mathrm{g} / \mathrm{dL})^{¥}$ & $61.98 \pm 2.96(30.15-109.40)$ & $73.49 \pm 6.43(43.68-108.44)$ & 0.060 \\
$\mathrm{Cu}(\mu \mathrm{g} / \mathrm{dL})^{¥}$ & $85.53 \pm 4.48(37.32-167.92)$ & $81.59 \pm 4.41(38.98-97.30)$ & 0.263 \\
$\mathrm{Cu} / \mathrm{Zn} \mathrm{ratio}{ }^{¥}$ & $1.47 \pm 0.11(0.58-2.84)$ & $1.20 \pm 0.14(0.72 \pm 2.22)$ & 0.392 \\
\hline ¥:Mean \pm standard deviation (range) & &
\end{tabular}

$¥:$ Mean \pm standard deviation (range) 
There was no significant relationship between the serum trace element concentrations and $\mathrm{Cu} / \mathrm{Zn}$ ratio with aortic involvement in the Group I ( $p>0.05)$ (Table 5).

Table 5: Comparison of serum trace element levels in the Group I based on aortic involvement.

\begin{tabular}{lccc} 
& $\begin{array}{c}\text { No or mild aortic } \\
\text { involvement }(\mathrm{n}=30)\end{array}$ & $\begin{array}{c}\text { Medium or severe aortic } \\
\text { involvement }(\mathrm{n}=31)\end{array}$ & $\mathrm{p}$ \\
\hline $\mathrm{Se}(\mu \mathrm{g} / \mathrm{dL})^{*}$ & $43.09 \pm 2.89(9.77-72.15)$ & $43.08 \pm 2.29(17.12-79.65)$ & 0.315 \\
$\mathrm{Zn}(\mu \mathrm{g} / \mathrm{dL})^{*}$ & $65.27 \pm 3.65(30.15-108.64)$ & $64.04 \pm 4.22(32.63-109.40)$ & 0.061 \\
$\mathrm{Cu}(\mu \mathrm{g} / \mathrm{dL})^{*}$ & $84.72 \pm 4.95(40.70-157.14)$ & $84.31 \pm 5.03(37.32-167.92)$ & 0.147 \\
$\mathrm{Cu} / \mathrm{Zn} \mathrm{ratio}{ }^{*}$ & $1.37 \pm 0.14(0.65-2.84)$ & $1.42 \pm 0.12(0.58 \pm 2.57)$ & 0.159 \\
\hline$¥:$ Mean \pm standard deviation $($ range $)$ & &
\end{tabular}

There was no significant relationship between serum trace element concentration and $\mathrm{Cu} / \mathrm{Zn}$ ratio and pulmonary hypertension in the patient group ( $p>0.05$ ) (Table 6).

Table 6: Comparison of serum trace element levels in the Group I based on pulmonary hypertension status.

Absence of pulmonary

\begin{tabular}{lccc} 
Variable & $\begin{array}{c}\text { Absence of pulmonary } \\
\text { hypertension }(\mathrm{n}=29)\end{array}$ & $\begin{array}{c}\text { Presence of pulmonary } \\
\text { hypertension }(\mathrm{n}=32)\end{array}$ & $\mathrm{p}$ \\
\hline $\mathrm{Se}(\mu \mathrm{g} / \mathrm{dl})^{*}$ & $43.08 \pm 2.78(15.78-79.65)$ & $43.10 \pm 2.45(9.77-72.15)$ & 0.932 \\
$\mathrm{Zn}(\mu \mathrm{g} / \mathrm{dl})^{*}$ & $58.69 \pm 3.06(34.00-103.04)$ & $63.22 \pm 3.79(30.15-99.48)$ & 0.659 \\
$\mathrm{Cu}(\mu \mathrm{g} / \mathrm{dl})^{*}$ & $87.25 \pm 4.93(40.70-157.14)$ & $81.98 \pm 4.99(37.32-167.92)$ & 0.225 \\
$\mathrm{Cu} / \mathrm{Zn} \mathrm{ratio}{ }^{*}$ & $1.51 \pm 0.13(0.65-2.84)$ & $1.28 \pm 0.12(0.58 \pm 2.66)$ & 0.214 \\
\hline$¥:$ Mean \pm standard deviation (range) & &
\end{tabular}

\section{Discussion}

This study demonstrated that rheumatic heart disease (RHD) is accompanied by decreased Se and $\mathrm{Zn}$ concentrations and increased $\mathrm{Cu}$ concentrations.

Deteriorated trace element levels in cardiac diseases such as atherosclerosis, idiopathic dilated cardiomyopathy, and chronic heart failure have been reported in the literature [18-21]. Likewise, possible changes in the trace element levels in rheumatic heart disease (RHD) have been reported [22,23]. However, serum trace element levels have not been studied in detail. Nutritional deficiencies and infectious diseases are common and show complex interactions leading to poor clinical effects. Such combinations are evident in developing countries, especially in rural areas. Many nutritional elements (such as Se, $\mathrm{Cu}$, and $\mathrm{Zn}$ ) modulate the immune function and affect the sensitivity of the host to the infection [24,25]. It is also essential for optimal functioning of organs and tissues. For this reason, trace elements can play a critical role in cardiovascular diseases.

Selenium is an essential trace element for protecting the immune system and oxidative functions. It acts as both an antioxidant and an anti-inflammatory agent. Because hydrogen reduces peroxide and phospholipid hydroperoxidase, it also reduces the levels of free radicals and reactive oxygen species [26].

$\mathrm{Zn}$ and $\mathrm{Cu}$, like $\mathrm{Se}$, have similar effects on immunological systems [24]. Increased $\mathrm{Cu}$ levels and $\mathrm{Cu} / \mathrm{Zn}$ ratio are indicative of the severity of an inflammatory process, high levels demonstrating a more serious inflammatory process. It has been suggested that high levels of serum $\mathrm{Cu}$ and low $\mathrm{Zn}$ (therefore, high $\mathrm{Cu} / \mathrm{Zn}$ ratio) are low-rate acute phase reactants in patients with sclerotic aortic valves. Studies with similar patient groups have also been supported by moderately elevated Creactive protein levels [27]. Using serum trace element levels of healthy individuals, sclerotic aortic valves of operated patients, and aortic valves from autopsies, Nyström-Rosader et al. [28] supported that serum $\mathrm{Cu}$ and $\mathrm{Zn}$ concentrations are indicative of the severity of infection and inflammatory process.

Various immunologic and inflammatory changes have long been reported to play a key role in the pathogenesis and prognosis of RHD. According to many theories, the pathogenesis of RHD is explained by an abnormal immunological response [1, 29]. It was also stated that these responses are related to changes in trace element levels. Previous studies have focused on the trace element levels (especially $\mathrm{Zn}$ ) in the tissue samples of RHD $[22,23]$. These studies have shown that the $\mathrm{Zn}$ levels in the samples taken from heart valves of postmortem cases of RCC are significantly lower than those of the control group. Govindarajo et al. [22] have shown that low levels of $\mathrm{Zn}$ in RHD may affect cell-mediated immunity and increase rheumatic activity and patients' susceptibility to infections. Koşar F. and colleagues [4] observed that serum $\mathrm{Zn}$ and Se concentrations were lower and $\mathrm{Cu}$ and $\mathrm{Cu} / \mathrm{Zn}$ ratios were significantly higher in RHD, and they observed that these were important parameters in the development of the rheumatic process, but they did not find a meaningful relationship with the severity of the functional class, which is indicative of the severity of the disease. Chlamydia pneumonia contributes to the development of atherosclerosis and RHD. Nyström-Rosader and colleagues observed that serum and sclerotic occult elemental levels play an important role in this contribution of Chlamydia pneumonia [30], facilitating the development of active infection by Chlamydia pneumonia and adversely affecting the immune system of the brain.

Low Se levels have been demonstrated in the inflamed heart in acute viral myocarditis [31]. Especially feeding with nutrients deficient from Se is known by its negative effect on the immune system. As a result, more virulent virus variants are selected and they contribute to a heavier disease transmission [32]. In addition, Se deficiency has been associated with many different cardiovascular diseases such as Keshan and Chagas [33].

In our study, it was determined that the serum concentrations of Se and $\mathrm{Zn}$ were significantly lower in patients with RHD than in the healthy control group, and that these patients had a significantly higher serum $\mathrm{Cu}$ level and a higher $\mathrm{Cu} / \mathrm{Zn}$ ratio than the control group. However, there was no difference between the groups in which trace element concentrations and $\mathrm{Cu} / \mathrm{Zn}$ ratios were classified according to the presence of Wilkins score, aortic valve involvement, and presence of pulmonary hypertension, which are echocardiographic findings showing the severity of patients' illnesses. We found that the echocardiographic parameters LV end-systolic diameter and left atrium diameters were significantly larger in the patient group than the control group, and the ejection fraction and fractional shortening were significantly lower.

However, we could not explain an underlying mechanism by which serum $\mathrm{Zn}$ and Se element levels could be reduced, and we could not detect a situation that would increase oxidative stress or inflammation and affect serum $\mathrm{Zn}$ or $\mathrm{Se}$ levels. Because RHD is an inflammatory condition, it is not surprising that low levels of Se and $\mathrm{Zn}$ are seen in our patients. In other words, it can be said that the changes in trace element levels in these patients may be the result of the current inflammatory process, as well as the inadequate intake of dietary trace elements. A second finding in this study is that the increase in serum $\mathrm{Cu}$ concentration and $\mathrm{Cu} / \mathrm{Zn}$ ratio reflects an increased or persistent inflammatory process in this disease, because the $\mathrm{Cu}$ concentrations and $\mathrm{Cu} / \mathrm{Zn}$ ratios are significantly higher in these patients compared to the control group. There was no significant relationship between the third trace element profile and the groups we classified according to Wilkins score, aortic valve involvement, and the presence of pulmonary hypertension, which were echocardiographic findings showing the severity of the disease. It is known and expected that among the echocardiographic parameters the left atrium diameter is significantly larger in the patient group than in the control group. Although the ejection fraction and fractional shortening measurements were significantly lower than the control group, 
we observed that left ventricular function was maintained in the patient group.

As a result, we report that RHD is accompanied by decreased $\mathrm{Se}$ and $\mathrm{Zn}$ concentrations and increased $\mathrm{Cu}$ concentrations. We can say that changes in trace element concentration may predispose to RHD, but may also give rise to the development of some factors, which may lead to the disease. As they may contribute to the development of many cardiovascular diseases, the low serum levels of Se and $\mathrm{Zn}$ may have also significantly contributed to the development of RHD. In childhood, malnutrition and poor hygienic conditions contribute to the decrease of Se and Zn levels [32]. Of course, it is the most economical way to prevent the development of RHD, which is still a significant health problem in Turkey. Therefore, it can be expected that rich and balanced nutrition in terms of trace elements can contribute to the reduction of the incidence of RHD by providing support for a healthy immune system.

When we translate our results into clinical practice, some limitations of this study must be kept in mind. First, our sample is from a restricted area and a limited number of carefully selected participants. Although the results of a study from the same area [4] supports our findings, there is a need for a wider range of data to verify the accuracy and precision of these results. Secondly, the serum levels of the measured elements depend on the nutritional status and oral intake such as mineral supplements and medications. For this reason, it is difficult to make final conclusions by a one-time analysis. Also the time gap between data collection and study reporting, which was due to personal problems of the main author, can be mentioned as a limitation.

In conclusion, assessment of serum trace element levels in patients with well-settled RHD may not be clinically useful, but evaluation of serum trace element levels and providing nutritional trace element support in the acute phase may reduce the development of RHD. Besides, elevated serum $\mathrm{Cu}$ levels and $\mathrm{Cu} / \mathrm{Zn}$ ratio can be used as ongoing inflammatory process markers. For this reason, evaluation of serum trace element levels seems feasible in patients with RHD.

\section{References}

1. Amigo MC, Martinez-Lavin M, Reyes PA. Acute rheumatic fever. Rheum Dis Clin North Am. 1993;19:333-50.

2. Licciardi F, Scaioli G, Mulatero R, Marolda A, Delle Piane M, Martino $\mathrm{S}$, et al. Epidemiologic Impact of the New Guidelines for the Diagnosis of Acute Rheumatic Fever. J Pediatr. 2018;198:25-8.

3. Barandier C, Tanguy S, Pucheu S, Boucher F, De Leiris J. Effect of antioxidant trace elements on the response of cardiac tissue to oxidative stress. Ann N Y Acad Sci. 1999;874:138-55.

4. Kosar F, Sahin I, Acıkgöz N, Aksoy Y, Kucukbay Z, Cehreli S. Significance of Serum Trace Element Status in Patients with Rheumatic Heart Disease: A Prospective Study. Biol Trace Elem Res. 2005;107:110

5. Alissa EM. Antioxidants and Cardiovascular Disease: A summary of the Evidence. J Cardiovasc Dis. 2015;3:347-56.

6. Song Y, Cook NR, Albert CM, Van Denburgh M, Manson JE. Effects of vitamins $\mathrm{C}$ and $\mathrm{E}$ and $\beta$-carotene on the risk of type 2 diabetes in women at high risk of cardiovascular disease: a randomized controlled trial-. Am J Clin Nutr. 2009;90:429-37.

7. Von Elm E, Altman DG, Egger M, Pocock SJ, Gøtzsche PC, Vandenbroucke JP. The Strengthening the Reporting of Observational Studies in Epidemiology (STROBE) statement: Guidelines for reporting observational studies. PLoS Med. 2007;4:1623-7.

8. Rhodes KL, Rasa MM, Yamamoto LG. Acute Rheumatic Fever: Revised Diagnostic Criteria. Pediatr Emerg Care. 2018;34:436-40.

9. Wilkins GT, Weyman AE, Abascal VM, Block PC, Palacios IF. Percutaneous balloon dilatation of the mitral valve: An analysis of echocardiographic variables related to outcome and the mechanism of dilatation. Heart. 1988;60:299-308.

10. Vahanian A, Baumgartner H, Bax J, Butchart E, Dion R, Filippatos G, et al. Guidelines on the management of valvular heart disease: The Task
Force on the Management of Valvular Heart Disease of the European Society of Cardiology. Eur Heart J. 2007;28:230-68.

11. Yamamoto K, Masuyama T, Tanouchi J, Uematsu M, Doi Y, Mano T, et al. Peak early diastolic filling velocity may decrease with preload augmentation: effect of concomitant increase in the rate of left atrial pressure drop in early diastole. J Am Soc Echocardiogr. 1993;6:245-54.

12. Karpuz H, Ikitimur B. [Echocardiographic evaluation of aortic stenosis]. Ana Kar Der. 2002;2:65-9.

13. Godley RW, Green D, Dillon JC, Rogers EW, Feigenbaum H, Weyman AE. Reliability of two-dimensional echocardiography in assessing the severity of valvular aortic stenosis. Chest. 1981;79:657-62.

14. Stoddard MF, Hammons RT, Longaker RA. Doppler transesophageal echocardiographic determination of aortic valve area in adults with aortic stenosis. Am Heart J. 1996;132:337-42.

15. Yeager M, Yock PG, Popp RL. Comparison of Doppler-derived pressure gradient to that determined at cardiac catheterization in adults with aortic valve stenosis: Implications for management. Am J Cardiol. 1986;57:644-8.

16. Bai AD, Steinberg M, Showler A, Burry L, Bhatia RS, Tomlinson GA, et al. Diagnostic accuracy of transthoracic echocardiography for infective endocarditis findings using transesophageal echocardiography as the reference standard: a meta-analysis. J Am Soc Echocardiogr. 2017;30:639-46.

17. Faul F, Erdfelder E, Lang A-G, Buchner A. G*Power 3:A flexible statistical power analysis program for the social, behavioral, and biomedical sciences. Behav Res Methods. 2007;39:175-91.

18. Oster O, Prellwitz W. Selenium and cardiovascular disease. Biol Trace Elem Res. 1990;24:91-103.

19. Bai-Song N, Chung-Seng L, Li-Hua C. Significance of low levels of blood selenium in dilated cardiomyopathy. Bio Trace Elem Res. 1986 Dec;99(12):948-9.

20. Klevay LM. The role of copper, zinc and other chemical elements in ischemic heart disease . eds. CRC, Boca Raton, FL, pp. 1984;129-157. In: Rennert OM, Chan WY, editors. Metabolism of trace metals in man. Boca Raton: CRC; 1984. p. 129-57.

21. Yu X, Huang L, Zhao J, Wang Z, Yao W, Wu X, et al. The Relationship between Serum Zinc Level and Heart Failure: A Meta-Analysis. Biomed Res Int. 2018;2018:2739014.

22. Govindaraju V, Prabhudev N, Gurappa M, Jawali VS, Chandrasekhara PM, Manjunath CN. Zinc in rheumatic heart valves. J Assoc Physicians India. 1993;41:653-4.

23. Durak I, Akyol Ö, Es MU, Canbolat O, Akpoyraz M. Element structure in stenotic mitral valves. Am J Cardiol. 1993;71:355.

24. Chandra RK. Trace Element Regulation of Immunity and Infection. J Am Coll Nutr. 1985;4:5-16.

25. Rotruck JT, Pope AL, Ganther HE, Swanson AB, Hafeman DG, Hoekstra WG. Selenium: biochemical role as a component of glutathione peroxidase. Science. 1973;179:588-90.

26. El-Ghazaly MA, Fadel N, Rashed E, El-Batal A, Kenawy SA. Antiinflammatory effect of selenium nanoparticles on the inflammation induced in irradiated rats. Can J Physiol Pharmacol. 2017;95:101-10.

27. Galante A, Pietroiusti A, Vellini M, Piccolo P, Possati G, De Bonis M, et al. C-reactive protein is increased in patients with degenerative aortic valvular stenosis. J Am Coll Cardiol. 2001;38:1078-82.

28. Nystrom-Rosander C, Lindh U, Friman G, Lindqvist O, Thelin S, Ilback $\mathrm{N}-\mathrm{G}$. Trace element changes in sclerotic heart valves from patients are expressed in their blood. Biometals. 2004;17:121-8.

29. Goldstein I, Halpern B, Robert L. Immunological relationship between streptococcus A polysaccharide and the structural glycoproteins of heart valve. Nature. 1967;213:44-7.

30. Nyström-Rosander C, Lindh U, Ilbäck NG, Hjelm E, Thelin S, Lindqvist $\mathrm{O}$, et al. Interactions between Chlamydia pneumoniae and trace elements: A possible link to aortic valve sclerosis. Biol Trace Elem Res. 2003;91:97-110.

31. Funseth E, Lindh U, Friman G, Ilbäck NG. Relation between trace element levels in plasma and myocardium during coxsackievirus B3 myocarditis in the mouse. BioMetals. 2000;13:361-7.

32. Levander OA, Ager ALJ, Beck MA. Vitamin E and selenium: contrasting and interacting nutritional determinants of host resistance to parasitic and viral infections. Proc Nutr Soc. 1995;54:475-87.

33. Chen X, Yang G, Chen J, Chen X, Wen Z, Ge K. Studies on the relations of selenium and Keshan disease. Biol Trace Elem Res. 1980;2:91-107. 